\title{
Tetrac downregulates $\beta$-catenin and HMGA2 to promote the effect of resveratrol in colon cancer
}

\author{
André Wendindondé Nana1, Yu-Tang Chin2,3, Chi-Yu Lin, Yih Ho5, James A Bennett6, Ya-Jung Shih³, Yi-Ru Chen ${ }^{3}$, \\ Chun A Changou1,7, Jens Z Pedersen, Sandra Incerpi ${ }^{9}$, Leroy F Liư3, Jacqueline Whang-Peng ${ }^{3}$, Earl Fu10, \\ Wen-Shan Li11,12, Shaker A Mousa13, Hung-Yun Lin'2,3,13,14 and Paul J Davis'13,15
}

1PhD Program for Cancer Molecular Biology and Drug Discovery, College of Medical Science and Technology, Taipei Medical University and Academia Sinica, Taipei, Taiwan

2PhD Program for Cancer Molecular Biology and Drug Discovery, College of Medical Science and Technology, Taipei Medical University, Taipei, Taiwan ${ }^{3}$ Taipei Cancer Center, Taipei Medical University, Taipei, Taiwan

${ }^{4}$ Center for Teeth Bank and Dental Stem Cell Technology and School of Dentistry, College of Oral Medicine, Taipei Medical University, Taipei, Taiwan ${ }_{5}^{5}$ chool of Pharmacy, College of Pharmacy, Taipei Medical University, Taipei, Taiwan

${ }^{6}$ Center for Immunology and Microbial Diseases, Albany Medical College, Albany, New York, USA

IIntegrated Laboratory, Center of Translational Medicine, Core Facility, Taipei Medical University, Taipei, Taiwan

${ }^{8}$ Department of Biology, University Tor Vergata, Rome, Italy

9Department of Sciences, University Roma Tre, Rome, Italy

10Department of Dentistry, Taipei Tzu Chi Hospital, Buddhist Tzu Chi Medical Foundation, Taipei, Taiwan

11Laboratory of Chemical Biology and Medicinal Chemistry, Institute of Chemistry, Academia Sinica, Taipei, Taiwan

12Doctoral Degree Program in Marine Biotechnology, National Sun Yat-Sen University, Taipei, Taiwan

13Pharmaceutical Research Institute, Albany College of Pharmacy and Health Sciences, Albany, New York, USA

14Traditional Herbal Medicine Research Center of Taipei Medical University Hospital, Taipei Medical University, Taipei, Taiwan

${ }^{15}$ Department of Medicine, Albany Medical College, Albany, New York, USA

Correspondence should be addressed to H-Y Lin: linhy@tmu.edu.tw

\begin{abstract}
The molecular pathogenesis of colorectal cancer encompasses the activation of several oncogenic signaling pathways that include the $\mathrm{Wnt} / \beta$-catenin pathway and the overexpression of high mobility group protein A2 (HMGA2). Resveratrol - the polyphenolic phytoalexin - binds to integrin $\alpha v \beta 3$ to induce apoptosis in cancer cells via cyclooxygenase 2 (COX-2) nuclear accumulation and p53-dependent apoptosis. Tetraiodothyroacetic acid (tetrac) is a de-aminated derivative of L-thyroxine $\left(\mathrm{T}_{4}\right)$, which - in contrast to the parental hormone - impairs cancer cell proliferation. In the current study, we found that tetrac promoted resveratrol-induced anti-proliferation in colon cancer cell lines, in primary cultures of colon cancer cells, and in vivo. The mechanisms implicated in this action involved the downregulation of nuclear $\beta$-catenin and HMGA2, which are capable of compromising resveratrol-induced COX-2 nuclear translocation. Silencing of either $\beta$-catenin or HMGA2 promoted resveratrol-induced anti-proliferation and COX-2 nuclear accumulation which is essential for integrin $\alpha \mathrm{v} \beta 3$-mediatedresveratrol-induced apoptosis in cancer cells. Concurrently, tetrac enhanced nuclear abundance of chibby family member 1 , the nuclear $\beta$-catenin antagonist, which may further compromise the nuclear $\beta$-catenin-dependent gene expression and proliferation. Taken together, these results suggest that tetrac targets $\beta$-catenin and HMGA2 to promote resveratrol-induced-anti-proliferation in colon cancers, highlighting its potential in anti-cancer combination therapy.
\end{abstract}

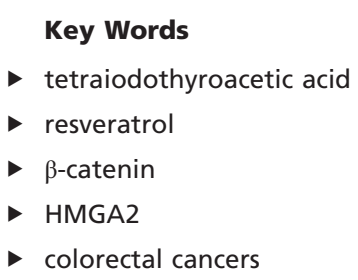

Endocrine-Related Cancer (2018) 25, 279-293 


\section{Introduction}

Colorectal cancer is a worldwide burden, ranked as the third most prevalent and the fourth most lethal of all malignant neoplasms (Torre et al. 2015). The clinical management of this cancer is hindered by the substantial rate of relapse, which often leads to patients' death. Novel therapeutic approaches are needed for this disease. The molecular pathogenesis of colon cancer encompasses the activation of several oncogenic signaling pathways, including the $\mathrm{Wnt} / \beta$-catenin pathway and the overexpression of the high mobility group protein A2-hook 2 (HMGA2) (Morin et al. 1997, Li et al. 2014).

The Wnt/ $\beta$-catenin pathway is an evolutionarilyconserved cell signaling system that mediates key physiological processes, but is also incriminated in the occurrence of several malignant neoplasms, including colon cancer. The activation of this pathway leads to the nuclear translocation of $\beta$-catenin, the downstream transcription factor. Nuclear $\beta$-catenin forms a transcriptional complex with co-activator members of the T-cell factor/lymphoid enhancer factor (TCF/LEF) family of transcription factors, to activate its target genes which are largely involved in cancer cell proliferation and metastasis (Clevers \& Nusse 2012). Within the nucleus, $\beta$-catenin's activity is modulated by co-repressors. One such co-repressor is chibby family member 1 , the gene product of $C B Y 1$, which antagonizes LEF at the promoter of $\beta$-catenin target genes (Takemaru et al. 2003).

HMGA2 is a non-histone chromatin-binding protein, which is abundantly expressed during embryogenesis, but barely detectable in normal adult tissues (Fusco \& Fedele 2007, Xi et al. 2016). High levels of HMGA2 have been consistently associated with the development and progression of many malignant neoplasms, both in preclinical and clinical studies (Fusco \& Fedele 2007, Wang et al. 2011, Günther et al. 2017). Accordingly, abundant expression of HMGA2 is correlated with metastasis and poor survival in colon cancer patients (Wang et al. 2011). Signaling via the phosphoinositide 3-kinase (PI3K) pathway, Ras/mitogen-activated protein kinase (MAPK) and oxidative stress has been implicated in vigorous activation of the HMGA2 gene (Ayoubi et al. 1999, Zentner et al. 2001).

Tetraiodothyroacetic acid (tetrac) is a de-aminated analog of the thyroid hormone L-thyroxine $\left(\mathrm{T}_{4}\right)$. Tetrac has been shown to inhibit cancer cell proliferation in vitro (Lin et al. 2011a, Mousa et al. 2012, Cohen et al. 2018) and in animal xenograft models (Yalcin et al. 2009). At its receptor on the extracellular domain of plasma membrane integrin $\alpha v \beta 3$, tetrac blocks cancer cell proliferation induced by thyroid hormones $\left(\mathrm{T}_{4}\right.$ and $\mathrm{T}_{3}$ ) (Schmohl et al. 2015). Importantly, $T_{4}$ has been shown to promote the nuclear accumulation of HMGA2 and $\beta$-catenin in a concentration-dependent manner in colorectal cancer cells with different $k$-RAS statuses (Lin 2016). However, independently of thyroid hormones, tetrac is capable of modulating the expression of genes regulated by cancer cells, which are important to cancer cell survival, angiogenesis, export of chemotherapeutic agents from cancer cells and repair of double-strand DNA breaks (Davis et al. 2014). Among such tetrac-regulated genes is CBY1, whose gene product is chibby family member 1 , the nuclear $\beta$-catenin antagonist mentioned above (Glinskii et al. 2009, Lin et al. 2016b). Additionally, tetrac enhances the therapeutic potential of other anti-cancer agents (Lin et al. 2011a, Lee et al. 2016, Leith et al. 2017).

Resveratrol is a polyphenolic antioxidant enriched in grape skin and other medicinal plants, which exerts therapeutic effects against a wide range of diseases including cancer in vitro and in vivo (Tseng et al. 2004, Lin et al. 2011b, Varoni et al. 2016). Resveratrol binds to a receptor, situated on integrin $\alpha v \beta 3$, to activate extracellular signal-regulated kinase-1 and -2 (ERK1/2) and to induce cyclooxygenase 2 (COX-2) nuclear accumulation, which is essential for resveratrol-induced anti-proliferation in several types of cancer cells (Chin et al. 2015). The nuclear activated complex of ERK1/2 and COX-2 stimulates Ser-15 phosphorylation of p53, which then induces apoptosis via the activation of its target genes in resveratrol-treated cells (Lin et al. 2008b, 2011b). Resveratrol-induced COX-2 nuclear accumulation can be inhibited by other hormonelike small molecules, which bind to integrin $\alpha v \beta 3$, such as dihydrotestosterone (DHT) (Chin et al. 2015) and $\mathrm{T}_{4}$ (Lin et al. 2007). Furthermore, resveratrol's anti-cancer properties are hindered by its low bioavailability, as it is rapidly and intensively metabolized by the intestine and the liver (Almeida et al. 2009, Cottart et al. 2010). Finding strategies to increase resveratrol's anti-proliferative efficacy against cancer, or in combination with other anti-cancer agents, is a potentially important path to investigate.

Against this background, we investigated whether tetrac potentiates resveratrol's anti-cancer properties in colorectal cancer; if it did so, we wanted to ascertain the molecular mechanisms involved. Results reported here indicate that tetrac-enhanced resveratrol-induced anti-proliferation in colon cancer by promoting nuclear COX-2 accumulation. The mechanisms implicated in this action involved the downregulation of nuclear $\beta$-catenin and HMGA2, which are capable of preventing 
resveratrol-induced COX-2 nuclear accumulation. Concurrently, tetrac triggered chibby family member 1 nuclear accumulation, which may further compromise the nuclear $\beta$-catenin-dependent gene expression and proliferation.

\section{Material and methods}

\section{Reagents}

Tetrac and resveratrol were purchased from Sigma-Aldrich (Sigma-Aldrich). Resveratrol was prepared as a stock concentration of $100 \mathrm{nM}$ in dimethyl sulfoxide (DMSO), and tetrac was dissolved in $\mathrm{KOH}$-propylene glycol at a concentration of $10^{-2} \mathrm{M}$. Reagents were conserved at $-20^{\circ} \mathrm{C}$. The final concentrations of solvents used to dissolve the reagents were tested for activity and did not affect the results of the experiments.

\section{Tissue samples and establishment of primary cultures of cancer cells}

Human colon cancer samples were obtained from colon cancer patients admitted to Shuang-Ho hospital (Taipei, Taiwan). The enrolled patients did not receive any chemotherapy or radiation therapy prior to surgery. A written informed consent approved by the Institutional Review Board of Taipei Medical University and affiliated hospitals (IRB number N201603078) was signed by all patients. Collected tissue samples were maintained in serum- and penicillin $(500 \mathrm{IU} / \mathrm{mL})$ - and streptomycin $(500 \mu \mathrm{g} / \mathrm{mL})$-containing saline at $4^{\circ} \mathrm{C}$ from the operating room to the research laboratory and processed immediately. Human colorectal primary cancer cells were established from the biopsies as previously described by Gharagozloo and coworkers (Gharagozloo et al. 2012).

\section{Cell cultures}

Human colorectal cancer HCT 116 (ATCC CCL-247) and HT-29 (ATCC HTB-38) cell lines were purchased from American Type Culture Collection (ATCC) by the Bioresource Collection and Research Center (BCRC, Hsinchu, Taiwan). These cell lines were tested and authenticated by the BCRC from which we acquired our cells. Primary colon cancer cells were established as described in the previous section, from colon cancer samples histologically confirmed by a medical pathologist. Primary cells were further analyzed for ki-67 expression and confirmed positive. HCT116 and HT-29 cells were used from passage 5 to passage 15. Primary cells were employed immediately until passage 4. All cells were cultured in RPMI-1640 medium (Gibco, Invitrogen) that was supplemented with 10\% FBS, penicillin $100 \mathrm{U} / \mathrm{mL}$ and streptomycin $100 \mu \mathrm{g} / \mathrm{mL}$. All cells were maintained at $37^{\circ} \mathrm{C}$ in a humidified incubator with $5 \% \mathrm{CO}_{2}$ and $95 \%$ air.

\section{Immunoblotting}

To extract total proteins, cells were lysed in 1-fold radioimmunoprecipitation assay (RIPA) buffer-containing 1-fold protease inhibitor and 1-fold phosphatase inhibitor. Nuclear proteins were extracted following the Thermo Scientific NE-PER Nuclear and Cytoplasmic Extraction Kit protocol (Thermo Scientific). The blotting technics are standard and have been described in several of our manuscripts (Chin et al. 2015, Lin et al. 2016a). Secondary antibodies were goat anti-rabbit IgG, rabbit anti-mouse IgG or rabbit anti-goat horseradish peroxidase, depending on the origin of the primary antibody. Immunoreactive proteins were detected using Amersham Imager 600 imaging system (GE Healthcare). Protein density was analyzed with ImageJ 1.5 software (NIH).

\section{Real-time PCR}

Total RNA was extracted from tumor tissues with Genezol (TriRNA Pure Kit (GZX050/GZX100/GZX200)|Geneaid) or from cultured cells with Illustra RNAspin Mini RNA Isolation Kit (GE Healthcare Life Sciences). Genomic DNA was eliminated with DNase I. Two micrograms of total RNA were reverse-transcribed with RevertAid $\mathrm{H}$ Minus First Strand cDNA Synthesis Kit (Life Technologies) into cDNA and used as the template for real-time PCR reactions and analysis. The real-time PCR reactions were performed are described in our previous studies (Chin et al. 2015). The genes primers and accession numbers are provided in Table 1.

\section{Cell proliferation assay}

Cells $\left(5 \times 10^{5}\right.$ cells per well for HCT116 and HT-29, $5 \times 10^{3}$ cells for colon 260417) were seeded on 6-well trays and synchronized by 24-h starvation in serum-deprived RPMI-1640 medium. Cells were then treated or not for $72 \mathrm{~h}$ in 10\% hormone-stripped FBS containing medium. Agents and medium were renewed daily. At the end of the experiments, cells were trypsinized and harvested for count with Countess automated cell (Invitrogen, Thermo Fisher Scientific). 
Table 1 Genes primers sequences and accession numbers.

\begin{tabular}{ll}
\hline Gene & Accession number \\
\cline { 1 - 2 } CTNNB1 & NM_001904 \\
HMGA2 & NM_003483.4 \\
HIF1A & NM_001243084.1 \\
MCL1 & NM_021960.4 \\
XIAP & NM_001167.3 \\
CCND1 & NM_053056 \\
C-MyC & NM_002467 \\
PCNA & BC062439.1 \\
MMP2 & NM_004530.5 \\
MMP9 & NM_004994.2 \\
MMP13 & NM_002427.3 \\
VEGFA & NM_001204384.1 \\
FGF2 & NM_002006.4 \\
ITGAV & NM_002210.4 \\
ITGB3 & NM_000212.2 \\
R18S & M10098 \\
\hline
\end{tabular}

\begin{tabular}{l} 
Forward primer $\left(5^{\prime} \rightarrow 3^{\prime}\right)$ \\
\hline CTGGTCCTTTTTGGTCGAGGA \\
GTTGGTCGCAGCTACATAAGA \\
TGAACGTCGAAAAGAAAAGTCTCG \\
CCAAGAAAGCTGCATCGAACC \\
CTGGCGCGAAAAGGTGGA \\
CAAGGCCTGAACCTGAGGAG \\
TTCGGGTAGTGGAAAACCAG \\
TCTGAGGGCTTCGACACCTA \\
ATCCAGACTTCCTCAGGCGG \\
TGTACCGCTATGGTTACACTCG \\
CCAGACTTCACGATGGCATTG \\
TACCTCCACCATGCCAAGTG \\
GAGAAGAGCGACCCTCACA \\
TCCGATTCCAAACTGGGAGC \\
CTGGTGTTTACCACTGATGCCAAG \\
GTAACCCGTTGAACCCCATT
\end{tabular}

\begin{tabular}{l} 
Reverse primer $\left(5^{\prime} \rightarrow 3^{\prime}\right)$ \\
\hline GCAAGGCTAGGGTTTGATAAAT \\
CAAAGGAACAGGGAGAAAGTCA \\
GGAAGTGGCAACTGATGAGC \\
CAAACCCATCCCAGCCTCTT \\
TGATGTCTGCAGGTACACAAGT \\
GATCACTCTGGAGAGGAAGCG \\
CAGCAGCTCGAATTTCTTCC \\
TCATTGCCGGCGCATTTTAG \\
CCTGGCAATCCCTTTGTATGTT \\
GGCAGGGACAGTTGCTTCT \\
GGCATCTCCTCCATAATTTGGC \\
GATGATTCTGCCCTCCTCCTT \\
TAGCTTTCTGCCCAGGTCC \\
AAGGCCACTGAAGATGGAGC \\
TGTTGAGGCAGGTGGCATTGAAGG \\
CCATCCAATCGGTAGTAGCG
\end{tabular}

Reverse primer $\left(5^{\prime} \rightarrow 3^{\prime}\right)$ GGAAGTGGCAACTGATGAGC GATCACTCTGGAGAGGAAGCG CAGCAGCTCGAATTTCTTCC CATTTTAG GGCATCT GATGATTCTGCCCTCCTCCTT AAGGCCACTGAAGATGGAGC CCATCCAATCGGTAGTAGCG

\section{MTT assay (cell viability assay)}

Colon cancer cells $\left(1 \times 10^{3}\right.$ cells per well) were seeded in 96-well plates and synchronized by 24 -h starvation in serum-deprived RPMI-1640 medium. Cells were then treated or not for $72 \mathrm{~h}$ in $10 \%$ hormone-stripped FBScontaining medium. Agents and medium were renewed on a daily basis. Cell proliferation was determined by incubating the cells with $200 \mu \mathrm{L}$ of fresh medium containing $1 \mathrm{mg} / \mathrm{mL} \quad 3$-(4,5-dimethylthiazol-2-yl)-2, 5-diphenyltetrazolium bromide (MTT) (Sigma-Aldrich) for $4 \mathrm{~h}$ at $37^{\circ} \mathrm{C}$. After removal of the MTT solution, the resulting formazan crystals were dissolved completely in dimethyl sulfoxide (DMSO) and the plates were read using a microplate reader (Anthos 2010; Biochrom, Cambridge, United Kingdom) by measuring the absorbance at $540 \mathrm{~nm}$. Quintuplicate wells were assayed for each experiment, and three independent experiments were performed.

\section{Small interfering RNA transfection}

Colon cancer cells were seeded in 6-well tissue culture plates $\left(10^{5}\right.$ cells/well), grown at $60 \% \sim 80 \%$ confluence and maintained in an antibiotic-free medium for $24 \mathrm{~h}$ before transfection. Just prior to transfection, the culture medium was removed, and cells were washed once with PBS, then transfected with HMGA2 siRNA (Thermo Fisher) or $\beta$-catenin siRNA (Cell Signaling Technology) with Lipofectamine 3000, in Opti-MEM I medium according to the manufacturer's instructions. After transfection, cultures were incubated at $37^{\circ} \mathrm{C}$ for $4 \mathrm{~h}$ and then placed in fresh culture medium for an additional $48 \mathrm{~h}$. Transfected cells were then treated with agents for Western blots experiments $(24 \mathrm{~h})$ or cell proliferation assays $(72 \mathrm{~h})$.

\section{Immunohistochemistry}

Tissue sections were dewaxed in xylene (Sigma-Aldrich) and rehydrated in alcohol (Sigma-Aldrich). Antigen retrieval was carried out by incubating tissue sections in citrate antigen retrieval buffer $(10 \mathrm{mM}$ citric acid, $0.05 \%$ Tween 20, pH 6.0) at $95^{\circ} \mathrm{C}$ for $40 \mathrm{~min}$ in a water bath. Endogenous peroxidase was blocked by incubation with Peroxidase Block and Protein Block (Novocastra Laboratories, Wetzlar, Germany) at room temperature, both for $5 \mathrm{~min}$. After 3 washes with phosphate-buffered saline (PBS) containing 0.1\% Tween 20 (PBST), slides were individually incubated for overnight with COX-2 (Santa Cruz 1745 1:200 dilution), HMGA2 (Genetex GTX100519; 1:200 dilution), $\beta$-catenin (BD Bioscience 1:200 dilution) or chibby family member 1 ((s-13) Sc-86379 1:200 dilution) antibodies at $4^{\circ} \mathrm{C}$. Tissue sections were then rinsed in PBST and post primary block (Novocastra Laboratories) was applied at room temperature for $15 \mathrm{~min}$, followed by a NovoLink Polymer Detection System (Novocastra Laboratories) for another $15 \mathrm{~min}$ at room temperature. Subsequently, slides were treated with 3'3-diaminobenzidine chromogen (Novocastra Laboratories) for $5 \mathrm{~min}$ and counterstained with hematoxylin (Novocastra Laboratories), then mounted and examined under Nikon Eclipse ci optical microscope imaging system (Nikon Eclipse ci, Nikon Instruments). Images were captured at magnification $400 \times$ with a scale bar of $50 \mu \mathrm{m}$.

\section{Confocal microscopy}

Exponentially growing primary colon cancer 260417 cells were seeded on sterilized cover glasses (Paul Marienfeld, Lauda-Königshofen, Germany). After $24 \mathrm{~h}$ of starvation, 
cells were treated with tetrac $10^{-7} \mathrm{M}$, resveratrol $10 \mu \mathrm{M}$ or their combination for another $24 \mathrm{~h}$. Cells were fixed with $4 \%$ paraformaldehyde in PBS for $10 \mathrm{~min}$ and then permeabilized in $0.06 \%$ Triton X-100 for $5 \mathrm{~min}$. The cells were incubated with a monoclonal antibody to $\beta$-catenin (ab16051; 1:500) or HMGA2 (Genetex; 1:400) followed by an incubation with Alexa-488-labeled goat anti-rabbit (ab150077; 1:500). Cells were next incubated in Hoechst stain (Hoechst 33258 Sigma-Aldrich 1:1000) and mounted in EverBrite Hardset mounting medium. The fluorescent signals from $\beta$-catenin and HMGA2 were recorded and analyzed with the TCS SP5 Confocal Spectral Microscope Imaging System (Leica Microsystems).

\section{Nude mouse ectopic xenograft model}

Female nude homozygous mice (BALB/cAnN.Cg-Foxn1nu/ CrlNarl) aged 5-6 weeks, with an average body weight of $22 \mathrm{~kg}$, were purchased from the National Laboratory of Animal Center (Taipei, Taiwan). All mice were handled in accordance with protocols approved by the Institutional Animal Care and Use Committee, National Defense Medical Center, Taipei, Taiwan (IACUC-15-340). Mice were inoculated subcutaneously in each flank, with $2 \times 10^{7}$ human colon cancer HCT 116 cells. At the onset of the tumors, animals were randomly assigned to 6 treatment groups containing 5 mice each: control; resveratrol $2.5 \mathrm{mg} / \mathrm{kg}$ per body weight; resveratrol $25 \mathrm{mg} / \mathrm{kg}$; tetrac $1 \mathrm{mg} / \mathrm{kg}$; tetrac $1 \mathrm{mg} / \mathrm{kg}$ combined with resveratrol $2.5 \mathrm{mg} / \mathrm{kg}$ and tetrac $1 \mathrm{mg} / \mathrm{kg}$ combined with resveratrol $25 \mathrm{mg} / \mathrm{kg}$. Tetrac and resveratrol were administered intraperitoneally, five days a week for resveratrol and twice a week for tetrac. Tumor volume and animal weight were measured once a week, and the tolerance of agents was evaluated on a daily basis. Animals were killed on day 21, as the tumor burden in the control group was unbearable for animals, in compliance with institutional guidelines. Half of the tumor tissue was formalin-fixed and paraffinembedded for immunohistochemistry. The other half was snap frozen in liquid nitrogen and stored at $-80^{\circ} \mathrm{C}$ for subsequent experiments.

\section{Statistical analysis}

Data were analyzed with IBM SPSS Statistics software, version 20.0 (SPSS). Statistical significance between multiple experimental groups was analyzed by one-way
ANOVA followed by a Bonferroni correction. $P$ value $<0.05$ was considered as statistically significant.

\section{Results}

Tetrac potentiates resveratrol-induced antiproliferation and COX-2 nuclear accumulation in colon cancer cells

Both tetrac and resveratrol inhibit cancer cell proliferation (Lin et al. 2011a). In order to assess the anti-proliferation induced by tetrac, resveratrol and their combination in colorectal cancer, HCT116 and HT-29 cancer cells were treated with different concentrations of resveratrol $(1,10$ or $100 \mu \mathrm{M}$ ), tetrac $10^{-7} \mathrm{M}$ alone or combined to resveratrol $(1 \mu \mathrm{M}$ or $10 \mu \mathrm{M})$ for $72 \mathrm{~h}$, after $24 \mathrm{~h}$ of starvation. Tetrac at a concentration of $10^{-7} \mathrm{M}$ significantly inhibited colorectal cancer cell proliferation (Fig. 1A and B). Similarly, resveratrol inhibited cancer cell proliferation in a concentration-dependent manner. Interestingly, tetrac enhanced the anti-proliferation effect of resveratrol in the combination treatments. Parallel studies on primary colon cancer 260417 cell cultures showed similar results (Fig. 1C). These results were further confirmed by MTT assays (Supplementary Fig. 1A, B and C, see section on supplementary data given at the end of this article).

Binding to its receptor situated on integrin $\alpha v \beta 3$, resveratrol induces apoptosis in cancer cells via activation of the ERK1/2 pathway. This leads to ERK1/2 phosphorylation and nuclear translocation, as well as nuclear accumulation of inducible COX-2, which is essential for integrin-dependent resveratrolinduced apoptosis (Lin et al. 2011b). To assess whether tetrac promotes resveratrol-induced COX-2 nuclear accumulation, colorectal cancer HCT116 (Fig. 1D) and HT-29 (Fig. 1E) cells were treated with resveratrol $(1 \mu \mathrm{M}$ or $10 \mu \mathrm{M})$, tetrac $10^{-7} \mathrm{M}$ or their combination for $24 \mathrm{~h}$ and nuclear proteins were extracted for Western blot analysis. Resveratrol, but not tetrac, induced COX-2 nuclear accumulation and p53-Ser15 phosphorylation (Fig. 1D and E). Noticeably, resveratrol-induced nuclear COX-2 accumulation and p53-Ser15 phosphorylation were enhanced with tetrac co-treatment (Fig. 1D and E). Parallel studies conducted in human primary colon cancer cell 260417 cultures showed comparable results (Fig. 1F). In addition, all cells expressed integrin $\alpha \mathrm{v} \beta 3$ subunits (Supplementary Fig. 2). 
A

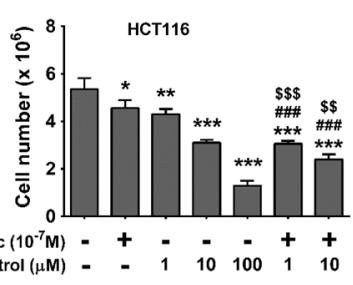

D

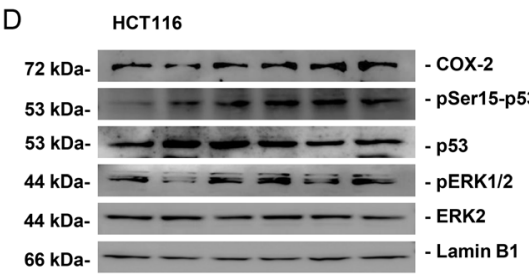

B
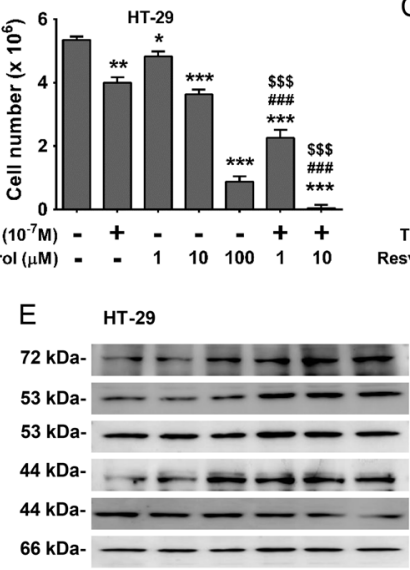

C

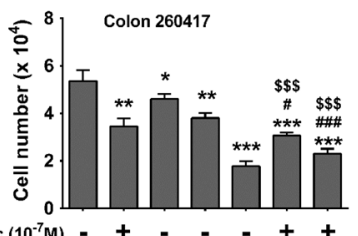

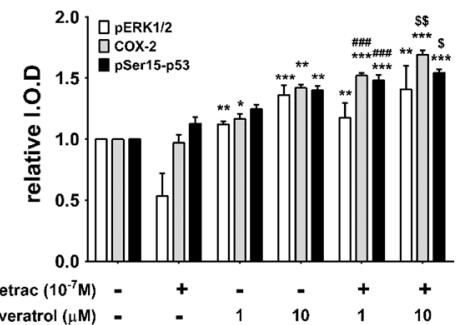
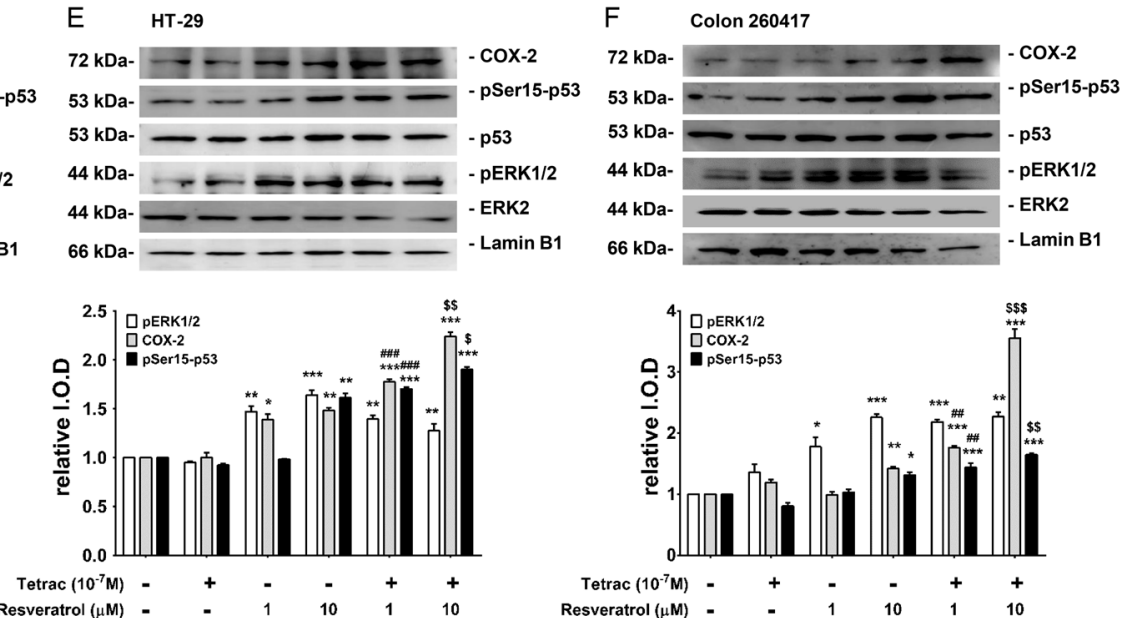

Figure 1

Effects of tetrac and resveratrol on colon cancer cells proliferation and COX-2 nuclear accumulation. Human colorectal cancer cell lines HCT116 (A), HT-29 (B) and a primary colon cancer cell, colon 260417 (C) were treated with different concentrations of resveratrol $(1,10$ or $100 \mu \mathrm{M})$, tetrac $10^{-7} \mathrm{M}$ alone or combined with resveratrol $(1 \mu \mathrm{M}$ or $10 \mu \mathrm{M})$ for $72 \mathrm{~h}$ and the total cell number was counted using a cell counter. Cells were maintained in serum-deprived medium for $24 \mathrm{~h}$ prior to agents' treatment. Data are displayed as the mean of 3 independent experiments run as triplicates. Data are displayed as the mean \pm s.D. ${ }^{*} P<0.05,{ }^{* *} P<0.01,{ }^{* *} P<0.001$ compared with control, ${ }^{\# P}<0.05, \# \# \#<0.001$ compared with tetrac $10^{-7} \mathrm{M}$ alone, ${ }^{\$ \$} P<0.01$, $\$ \$ \$ P<0.001$ compared with resveratrol alone at the same concentration. Human colorectal cancer cell lines HCT116 (D), HT-29 (E) and a primary colon cancer cell 260417 (F) were treated with different concentrations of resveratrol $(1 \mu \mathrm{M}$ and $10 \mu \mathrm{M})$, tetrac $10^{-7} \mathrm{M}$ alone or in combination with resveratrol for $24 \mathrm{~h}$, after $24 \mathrm{~h}$ of starvation. Nuclear proteins were extracted and Western blot experiments were performed. Protein density was analyzed with ImageJ and normalized to lamin B1. Resveratrol-induced COX-2 nuclear accumulation was enhanced by tetrac co-treatment. Representative results of

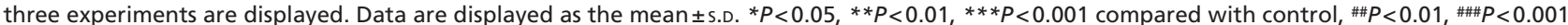
compared with resveratrol $1 \mu \mathrm{M}$ alone, $\$ P<0.05, \$ \$ P<0.01, \$ \$ P<0.001$ compared with resveratrol $10 \mu \mathrm{M}$ alone.

Tetrac inhibits actions of HMGA2 and $\beta$-catenin, but promotes chibby family member 1 nuclear accumulation in colon cancer cells

The oncogenic potential of HMGA2 has been demonstrated in almost all steps of carcinogenesis (Fusco \& Fedele 2007). $\mathrm{T}_{4}$ has been shown to induce the expression of HMGA2 in colorectal cancer HCT116 cells and to trigger nuclear translocation of HMGA2 and $\beta$-catenin in both HT-29 and HCT116 cells (Lin 2016). Given the antagonistic effect of tetrac on $\mathrm{T}_{4}$-induced cancer cell proliferation, we hypothesized that tetrac might affect the amount of HMGA2 in the nucleus. To verify this hypothesis, colon cancer HCT116 (Fig. 2A), HT-29 (Fig. 2B) cell lines and a primary colon cancer cell 310816 (Fig. 2C) were treated with different concentrations of tetrac for $24 \mathrm{~h}$, and nuclear proteins were extracted for Western blot analysis. As expected, tetrac inhibited HMGA2 nuclear protein amount in a concentration-dependent manner in all cell lines. Tetrac also downregulated PI3K phosphorylation (Fig. 2A, B and C), which has been identified as one of the key activators of HMGA2 expression in cancer settings (Ayoubi et al. 1999, Zentner et al. 2001).

$\mathrm{Wnt} / \beta$-catenin signaling is frequently dysregulated in colon cancer (Basu et al. 2016). Tetrac has been previously shown to induce $C B Y 1$ gene expression in breast cancer cells (Glinskii et al. 2009). Tetrac also antagonizes $\mathrm{T}_{4}$, which has been proven to induce $\beta$-catenin nuclear accumulation. Against this background, we sought to determine the effect of tetrac on the nuclear content of both $\beta$-catenin and its nuclear antagonist, chibby family member 1. To this end, colon cancer HCT116 and HT-29 cells were treated with different concentrations of tetrac for $24 \mathrm{~h}$ and nuclear proteins were extracted for Western blot analyses. Tetrac reduced nuclear content of $\beta$-catenin, but increased chibby family member 1 accumulation in both cells (Fig. 2A and B). Parallel studies conducted in http://erc.endocrinology-journals.org https://doi.org/10.1530/ERC-17-0450
2018 Society for Endocrinology Published by Bioscientifica Ltd. Printed in Great Britain 
A
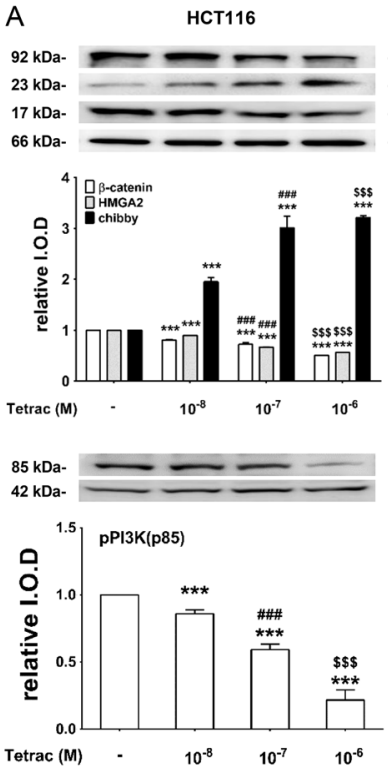

B

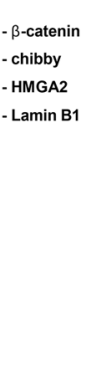

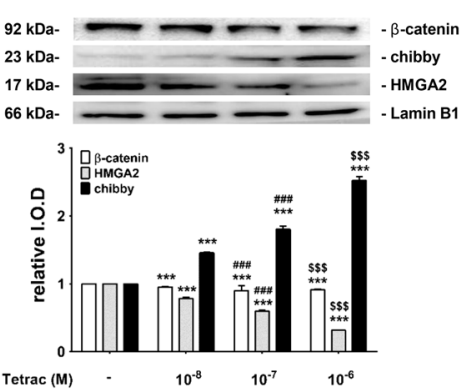

-pPI3K (p85) $85 \mathrm{kD}$ $-\beta$-actin$$
42 \mathrm{k}
$$
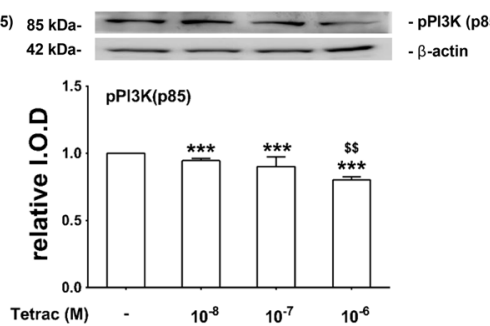
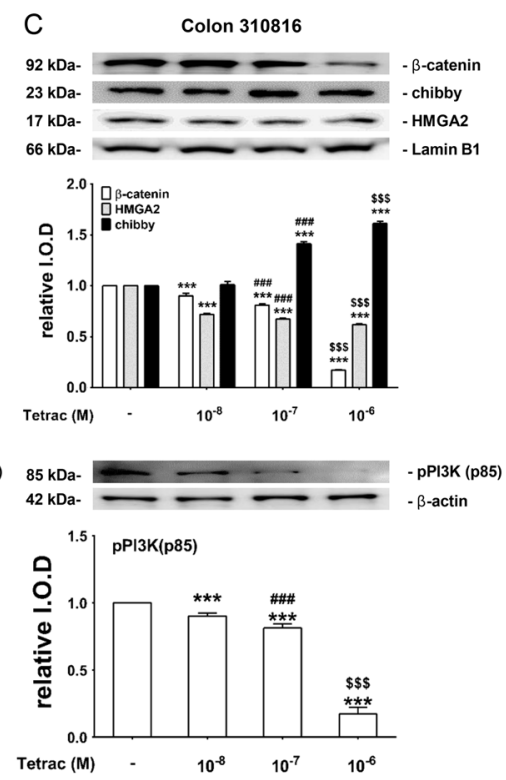

\section{Figure 2}

Tetrac regulates the nuclear accumulation of $\beta$-catenin, HMGA 2 and chibby family member 1 and the phosphorylation of PI3K. Human colorectal cancer cell lines, HCT116 (A), HT-29 (B) and a primary colon cancer cell culture 310816 (C) were treated with different concentration of tetrac (10-8 M to $10^{-6} \mathrm{M}$ ) for $24 \mathrm{~h}$, after $24 \mathrm{~h}$ of starvation. Western blot analyses were performed using nuclear proteins for $\beta$-catenin, HMGA 2 and chibby family member 1 and whole-cell lysates for pPI3K. Nuclear proteins were normalized to lamin B1 and whole-cell proteins to $\beta$-actin. Tetrac decreased the nuclear accumulation of $\beta$-catenin and HMGA 2 and the phosphorylation of PI3K, but enhanced the nuclear amount of chibby family member 1 . Representative results of three experiments are displayed. Data are displayed as the mean \pm s.D., at the level of significance $* * * P<0.001$ compared with control, \#\# $P<0.001$ compared with tetrac $10^{-8} \mathrm{M}, \$ \$ P<0.01$, $\$ \$ P<0.001$ compared with compared with tetrac $10^{-7} \mathrm{M}$.

primary colon cancer cells 310816 showed comparable results (Fig. 2C).

To further explore the effect of tetrac on $\beta$-catenin and HMGA2 in colon cancer cells, confocal microscopy experiments were conducted. Primary cultures of human colon cancer cells 260417 were treated with tetrac $10^{-7} \mathrm{M}$, resveratrol $10 \mu \mathrm{M}$ or their combination for $24 \mathrm{~h}$. This primary culture of human colon cancer cells exhibited high concentrations of both $\beta$-catenin and HMGA2, which was significantly reduced upon exposure to tetrac, alone or in combination with resveratrol (Fig. 3A and B).

\section{Silencing of HMGA2 or $\beta$-catenin promotes resveratrol-induced COX-2 nuclear accumulation and anti-proliferation}

We have shown that tetrac potentiates resveratrol-induced COX-2 nuclear accumulation, p53-Ser15 phosphorylation and subsequent anti-proliferation. We also proved that tetrac not only downregulated oncogenic HMGA2 and $\beta$-catenin but also potentiated the nuclear accumulation of chibby family member 1 . We then hypothesized that tetrac potentiation of resveratrol-induced COX-2 nuclear accumulation might depend upon HMGA2 and $\beta$-catenin downregulation. To examine these possibilities, HCT116 and HT-29 cells were treated with $\beta$-catenin siRNA or HMGA2 siRNA for $48 \mathrm{~h}$ and then treated or not with agents for an additional $24 \mathrm{~h}$ for Western blot analyses or $72 \mathrm{~h}$ for cell count assays. Nuclear proteins were extracted for Western blot analysis. Interestingly, the nuclear COX-2 accumulation and subsequent anti-proliferation induced by resveratrol was enhanced by both HMGA2 and $\beta$-catenin knockdown (Fig. 4A, B, C and D). These results indeed suggested that tetrac potentiated resveratrolinduced COX-2 nuclear accumulation by reducing the nuclear abundance of HMGA2 and $\beta$-catenin.

\section{Tetrac potentiates resveratrol anti-cancer activities in a nude mice xenograft model}

To investigate the potentiating effect of tetrac on resveratrol's anti-cancer effect in vivo, we conducted a mouse subcutaneous model of colon cancer. Both tetrac and resveratrol induced a significant anti-tumoral effect (Fig. 5A, B, D and Table 2). Resveratrol inhibited tumor growth in a concentration-dependent manner $(52.57 \%$ for resveratrol $2.5 \mathrm{mg} / \mathrm{kg}$ vs $80.99 \%$ for resveratrol $25 \mathrm{mg} / \mathrm{kg}$ ) (Table 2). At $1 \mathrm{mg} / \mathrm{kg}$, tetrac showed an inhibitory effect comparable to that of resveratrol at $25 \mathrm{mg} / \mathrm{kg}$ (78.93\% vs 80.99\%) (Table 2). Although not (c) 2018 Society for Endocrinology Published by Bioscientifica Ltd. Printed in Great Britain 
A

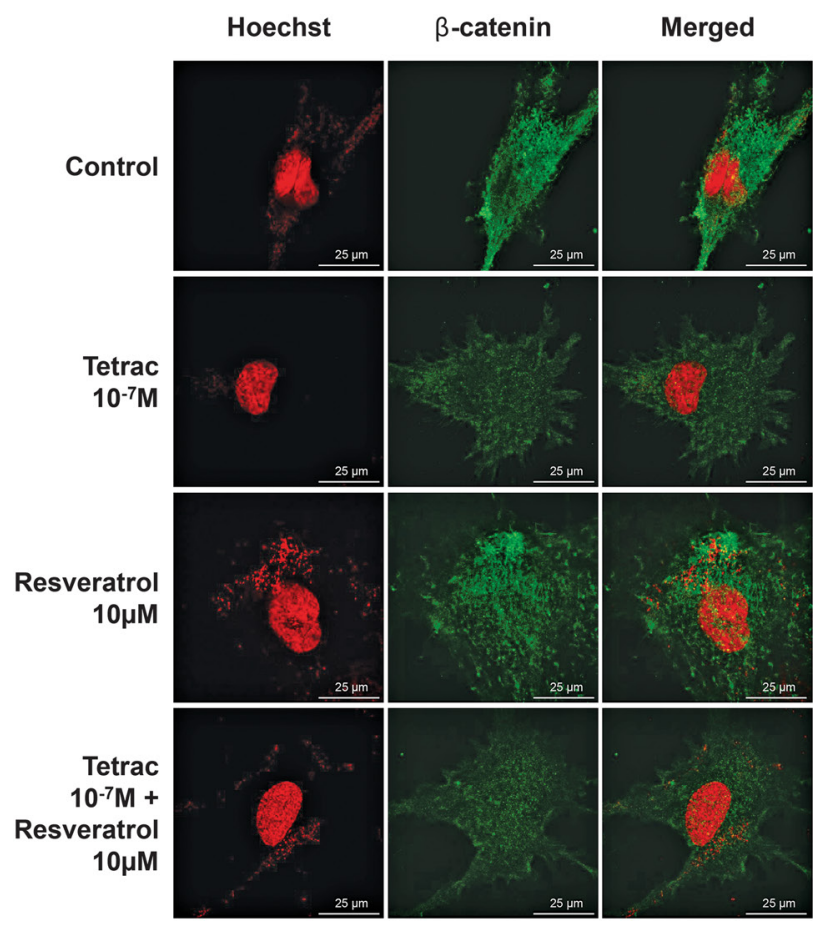

B

\section{Colon 260417}

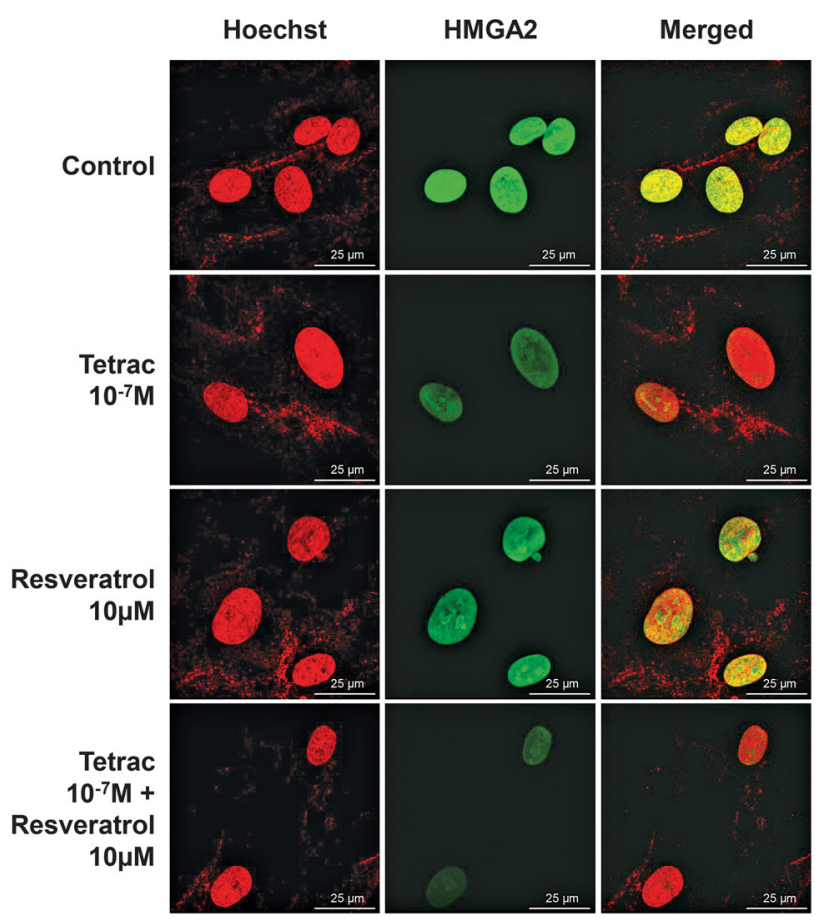

Figure 3

Tetrac reduces the accumulation of $\beta$-catenin and nuclear HMGA2. Human primary colon cancer cell cultures 260417 were treated with tetrac $10^{-7} \mathrm{M}$, resveratrol $10 \mu \mathrm{M}$ or their combination for $24 \mathrm{~h}$ and cells were examined by confocal microscopy. Tetrac downregulated total $\beta$-catenin alone or combined to resveratrol, as shown by the reduction of the green fluorescence (A). Furthermore, tetrac downregulated the nuclear protein HMGA2 (B) as indicated by the appearance of yellow fluorescence due to the superimposition of HMGA2 (green fluorescence) and nucleus (red fluorescence).

A
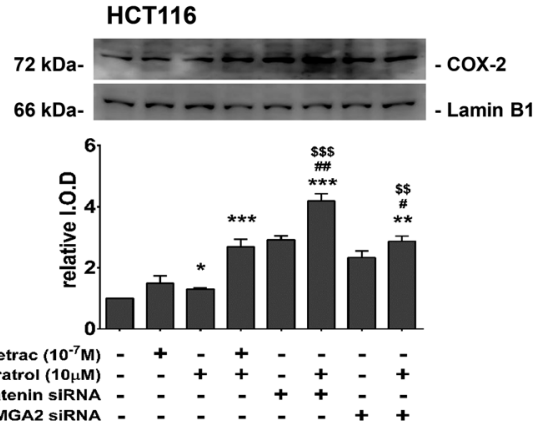

C
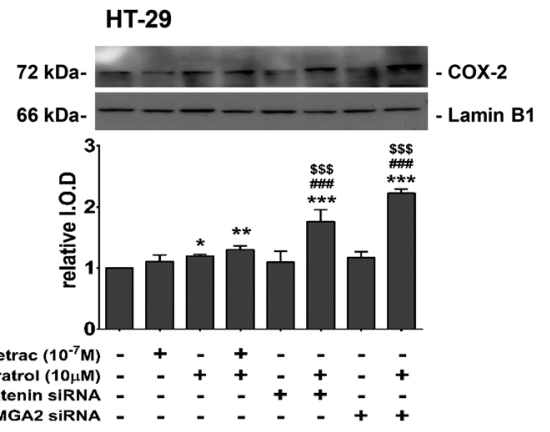

B

HCT116

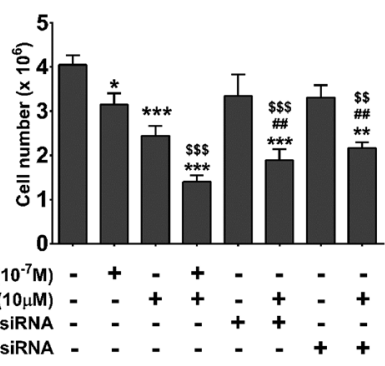

D

HT-29

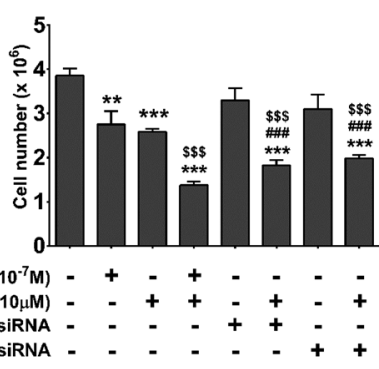

\section{Figure 4}

Silencing $\beta$-catenin or HMGA2 promotes resveratrol-induced COX-2 nuclear accumulation and antiproliferation. Human colorectal cancer cell lines, HCT116 (A and B) and HT-29 (C and D) were treated or not, with either siRNA of $\beta$-catenin or siRNA of HMGA2 for $48 \mathrm{~h}$, then were treated with agent for $24 \mathrm{~h}$ for Western blot analysis or $72 \mathrm{~h}$ for cell count assay. Nuclear proteins were extracted and Western blot analyses were performed. Nuclear COX-2 was normalized to lamin B1. Resveratrol-induced COX-2 nuclear accumulation and antiproliferation was enhanced by both $\beta$-catenin and HMGA2 silencing. Representative results of three experiments are shown. Data are displayed as the mean \pm s.D. ${ }^{*} P<0.05, * * P<0.01, * * * P<0.001$ compared with control (without siRNA treatment), $\# P<0.05, \# P<0.01, \# \# P<0.001$ compared with siRNA control alone, $\$ \$ P<0.01$, $\$ \$ P<0.001$ compared with resveratrol $10 \mu \mathrm{M}$ alone (without siRNA). 
B

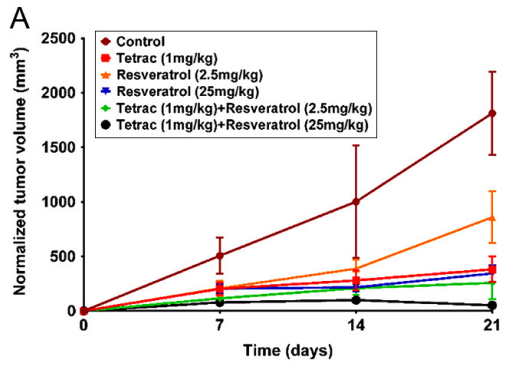

D

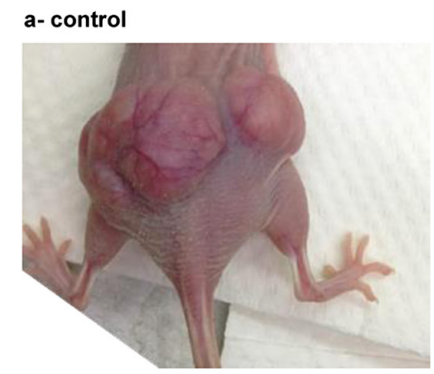

d- tetrac $1 \mathrm{mg} / \mathrm{kg}$

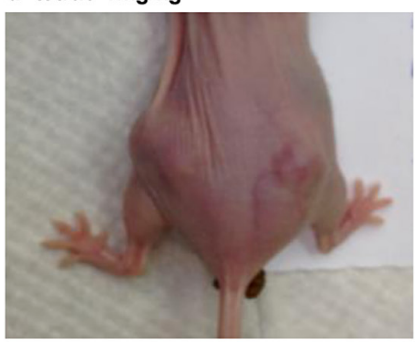

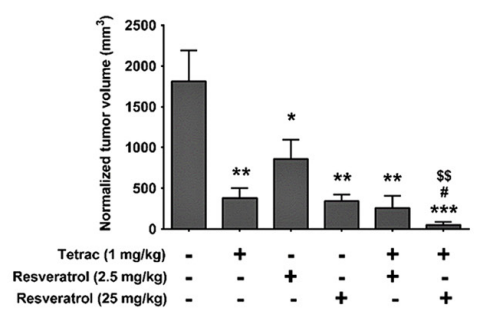

b- resveratrol $2.5 \mathrm{mg} / \mathrm{kg}$

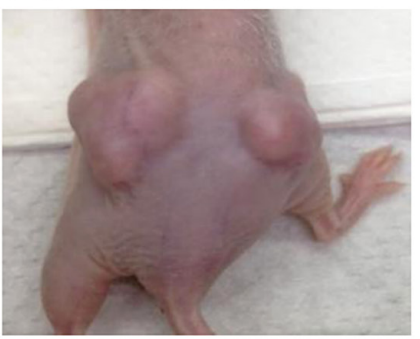

e- tetrac $1 \mathrm{mg} / \mathrm{kg}+$ resveratrol $2.5 \mathrm{mg} / \mathrm{kg}$

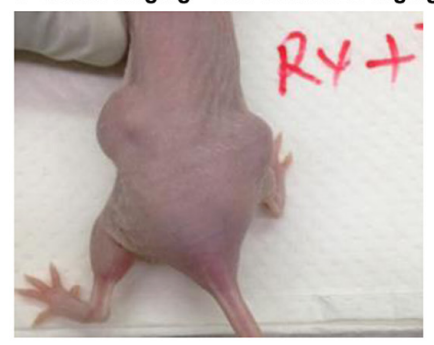

C

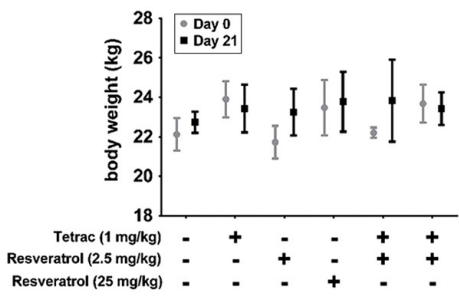

C- resveratrol $25 \mathrm{mg} / \mathrm{kg}$

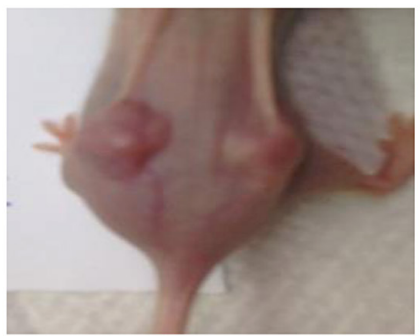

f- tetrac $1 \mathrm{mg} / \mathrm{kg}$ + resveratrol $25 \mathrm{mg} / \mathrm{kg}$

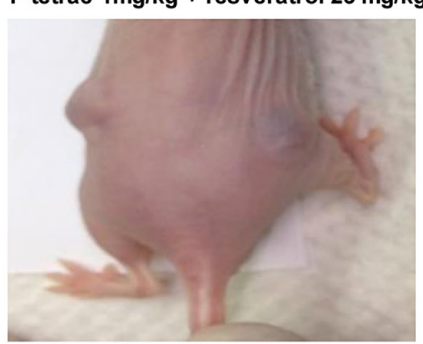

\section{Figure $\mathbf{5}$}

Tetrac and resveratrol inhibit cancer growth in mouse xenograft model. Human colon cancer HCT 116 cells ( $\left.2 \times 10^{7}\right)$ were injected bilaterally into nude mice. The tumor volume was normalized to the volume at treatment start. (A) Growth curve of tumors over time. (B) Between group comparison of final tumor volumes. ${ }^{*} P<0.05, * * P<0.01, * * * P<0.001$ compared with control, ${ }^{*} P<0.05$, compared with tetrac alone, $\$ \$ P<0.01$, compared with resveratrol $25 \mathrm{mg} / \mathrm{kg}$ alone. (C) Body weight. (D) Representative individuals of each group are shown.

statistically significant $(P=0.244)$, the combination of tetrac and resveratrol $2.5 \mathrm{mg} / \mathrm{kg}$ displayed a greater inhibitory effect compared to single agents at the same concentration $(85.77 \%$ vs $78.93 \%$ and $52.57 \%$ for tetrac $1 \mathrm{mg} / \mathrm{kg}$ and resveratrol $2.5 \mathrm{mg} / \mathrm{kg}$, respectively)

Table 2 Tumor growth inhibition percentages.

\begin{tabular}{|c|c|c|}
\hline Treatment groups & $\begin{array}{l}\text { Final tumor volume } \\
\qquad\left(\mathrm{mm}^{3}\right)\end{array}$ & $\begin{array}{c}\text { Inhibition } \\
(\%)^{*}\end{array}$ \\
\hline Control & $1812.5968 \pm 379.95$ & - \\
\hline Tetrac $1 \mathrm{mg} / \mathrm{kg}$ & $381.9487 \pm 116.62$ & 78.92809 \\
\hline Resveratrol $2.5 \mathrm{mg} / \mathrm{kg}$ & $859.5766 \pm 237.51$ & 52.57762 \\
\hline Resveratrol $25 \mathrm{mg} / \mathrm{kg}$ & $344.5496 \pm 75.78$ & 80.99138 \\
\hline $\begin{array}{l}\text { Tetrac } 1 \mathrm{mg} / \mathrm{kg} \text { + Resveratrol } \\
2.5 \mathrm{mg} / \mathrm{kg}\end{array}$ & $258.0172 \pm 149.52$ & 85.76533 \\
\hline $\begin{array}{l}\text { Tetrac } 1 \mathrm{mg} / \mathrm{kg} \text { + Resveratrol } \\
25 \mathrm{mg} / \mathrm{kg}\end{array}$ & $52.4302 \pm 30.82$ & 97.10745 \\
\hline
\end{tabular}

* Percentage reduction of tumor volume in the treatment groups as compared to the control group. Tumor volumes are presented as the mean \pm s.D.
(Table 2). The combination of high concentrations of resveratrol $(25 \mathrm{mg} / \mathrm{kg})$ and tetrac showed a potentiating effect, which was statistically significant compared to the anti-tumoral effect of single agents $(P=0.012$ vs tetrac, $P=0.006$ vs resveratrol $25 \mathrm{mg} / \mathrm{kg}$ ). More importantly, this combination inflected the tumor growth curve from the initial volume as displayed in the growth curve over time (Fig. 5A). All agents were well tolerated and did not affect the body weight of xenografted animals (Fig. 5C).

To further explore the molecular mechanisms implicated in tetrac's potentiation of resveratrol anticancer effect in vivo, we performed immunohistochemical staining of the xenograft tumor samples. Resveratrolinduced COX-2 nuclear accumulation, which was further enhanced by tetrac co-treatment (Fig. 6A). Likewise, tetrac reduced $\beta$-catenin and HMGA2 nuclear amount but enhanced chibby family member 1 nuclear accumulation (Fig. 6B). 
A

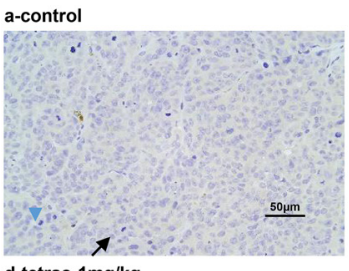

d-tetrac $1 \mathrm{mg} / \mathrm{kg}$

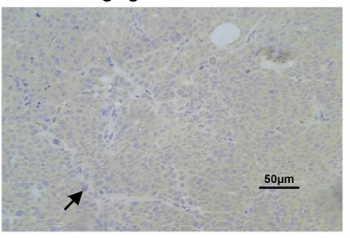

B
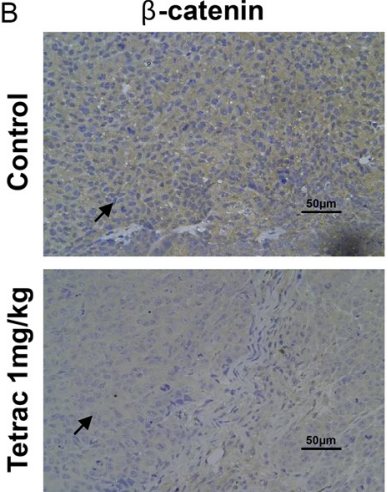

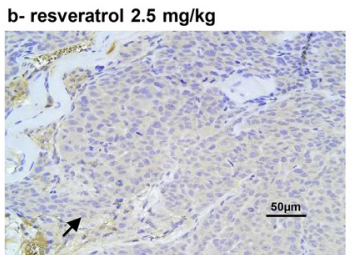

e-tetrac $1 \mathrm{mg} / \mathrm{kg}+$ resveratrol $25 \mathrm{mg} / \mathrm{kg}$

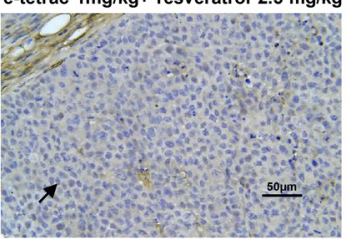

HMGA2
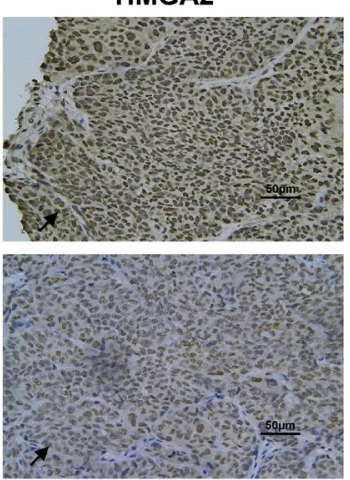

c- resveratrol $25 \mathrm{mg} / \mathrm{kg}$

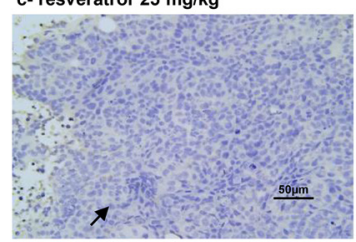

f-tetrac $1 \mathrm{mg} / \mathrm{kg}$ + resveratrol $25 \mathrm{mg} / \mathrm{kg}$

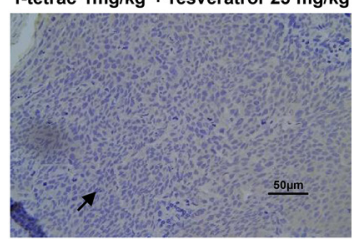

Chibby
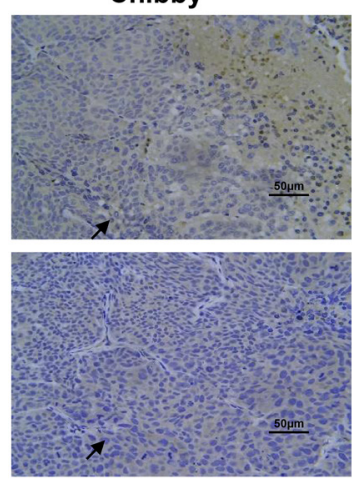

Figure 6

Tetrac and resveratrol regulate the accumulation of COX-2, $\beta$-catenin, HMGA2 and chibby family member 1 in tumor tissues. (A) Nuclear COX-2 expression (purple dots) was detected using IHC staining. (B) The expression of nuclear $\beta$-catenin (purple dots), nuclear HMGA2 (brown dots), and nuclear chibby family member 1 (purple dots) on tumor cells were also detected. Magnification $400 x$, scale bar $50 \mu \mathrm{m}$.
Taken together, these results indeed suggested that tetrac's potentiating effect on resveratrol-induced antiproliferation is subservient, on the one hand to the downregulation of nuclear $\beta$-catenin and nuclear HMGA2, and on the other hand to the increase of chibby family member 1 nuclear amount (Fig. 7).

\section{Tetrac and resveratrol affect the expression of cancer cell-regulated genes in vivo}

Next, we sought to further ascertain the synergistic effect of agents at the molecular level in vivo, by means of qPCR analyses using the harvested tumor samples. Both tetrac and resveratrol inhibited (a) CTNNB1, HMGA2 and HIF1A gene expression (Fig. 8A), (b) the apoptosis-related genes MCL1 and XIAP (Fig. 8B), (c) the proliferative genes CCND1, c-Myc and PCNA (Fig. 8C) (d) the metastasis-support genes MMP2, MMP9 and MMP13 (Fig. 8D) and the angiogenic genes VEGFA and FGF2 (Fig. 8E). A synergistic effect was also observed on most of these genes. These results indicated that, beyond its potentiating effect on resveratrol-induced COX-2 nuclear accumulation, tetrac expresses highly complex anti-tumoral effects in vivo.

\section{Discussion}

In this study, we have demonstrated that tetrac potentiates resveratrol-induced anti-proliferation in colorectal cancer cells. This potentiating effect was mediated, at least in part, by the inhibition of the nuclear accumulation of HMGA2 and $\beta$-catenin, and the increase of chibby family member 1. Both tetrac and resveratrol have been proven to induce anti-proliferation in different cancer cell lines. The current study is the first to assess the synergistic effect of resveratrol and tetrac in combination therapy in colon cancer, highlighting the implication of HMGA2, $\beta$-catenin and its nuclear antagonist chibby family member 1 . Knockdown of either HMGA2 or $\beta$-catenin enhanced resveratrol-induced COX-2 nuclear accumulation, which has been shown to be essential for integrin $\alpha v \beta 3$-mediated resveratrol-induced apoptosis in cancer cells (Lin et al. $2011 b$ ). Elsewhere, tetrac has been demonstrated to sensitize cancer cells to other anti-cancer agents or radiations (Rebbaa et al. 2008, Lee et al. 2016, Leith et al. 2017), underlining the potential of this anti-cancer agent in therapeutic combination.

There is a complex interplay between HMGA2 and Wnt signaling, both in physiological settings and in cancer. 


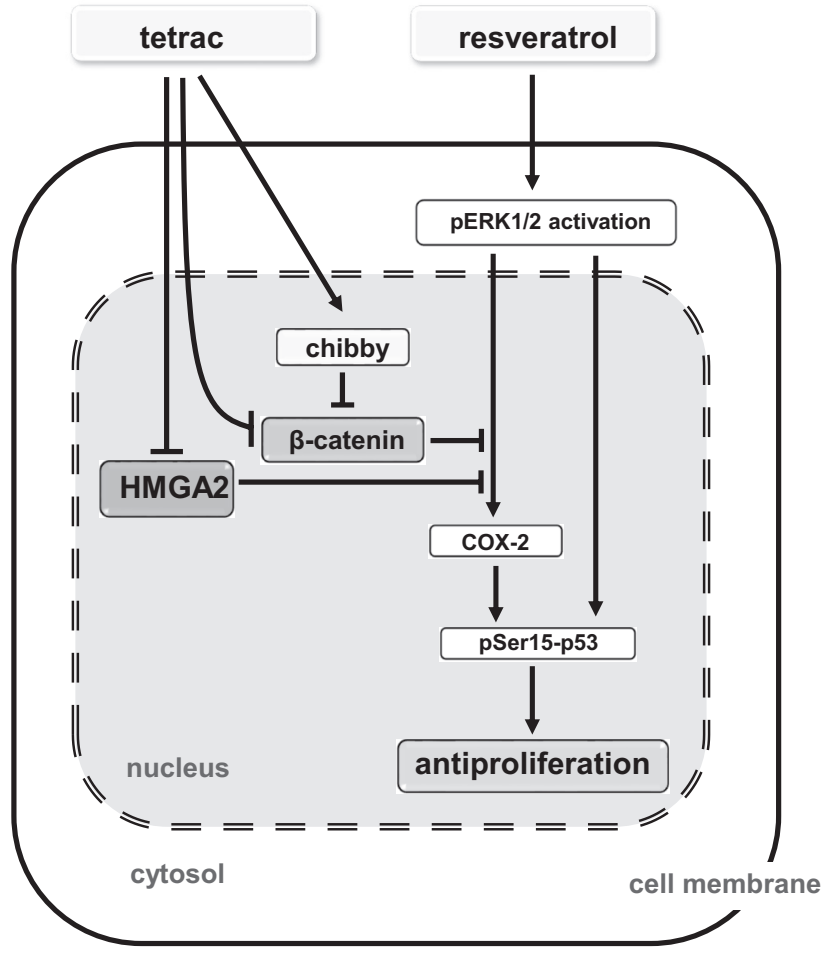

Figure 7

Molecular mechanisms. Resveratrol induces ERK1/2 phosphorylation and nuclear translocation, as well as COX-2 nuclear accumulation. Phosphorylated ERK $1 / 2$ cooperates with nuclear COX-2 to induce $\mathrm{p} 53$ phosphorylation at Serine 13 and subsequent anti-proliferation in cancer cells. Tetrac on the one hand, downregulates nuclear $\beta$-catenin and nuclear HMGA2, and on the other hand increases chibby family member 1 nuclear amount, which will further compromise $\beta$-catenin actions at its target genes promoters. Nuclear $\beta$-catenin and nuclear HMGA2 antagonize resveratrol-induced COX-2 nuclear accumulation, which is essential for resveratrol-induced apoptosis in cancer cells.

HMGA2 triggers senescence in human normal lung fibroblast WI-38 cells through downregulation of Wnt signaling (Shi et al. 2017). In malignancies, HMGA2 drives epithelial-to-mesenchymal transition (EMT) in gastric cancers via activation of $\mathrm{Wnt} / \beta$-catenin pathway (Zha et al. 2013). Furthermore, HMGA2 silencing impairs breast tumor development in Wnt1 transgenic mice (Morishita et al. 2013). However, other studies also indicate that WNT10B/ $\beta$-catenin pathway controls HMGA2 expression in triple-negative breast cancer cells (Wend et al. 2013). Therefore, there is a mutually promoting relationship between HMGA2 and Wnt to stimulate cancer progression. In our study, we found that tetrac inhibited the nuclear accumulation of both HMGA2 and $\beta$-catenin both in vitro and in in vivo models.

The relationship between thyroid dysfunction and cancer has long been an important topic in clinical investigations (Liao et al. 2010, Moeller \& Führer 2013).
Although some discrepancies in results have been found (Hercbergs et al. 2010), partially owing to differences in experimental designs, epidemiological studies involving large cohorts suggest a causal link between hyperthyroidism and cancer (Khan et al. 2016). The biological plausibility of these epidemiological observations is based on the fact that $\mathrm{T}_{4}$ exerts non-genomic activities that promote cancer cell proliferation via its receptor on integrin $\alpha v \beta 3$. At the same site, $\mathrm{T}_{4}$ is able to impair resveratrol's anti-cancer features (Lin et al. 2008a). However, tetrac, which shares a structural analogy with $\mathrm{T}_{4}$, can compete at the same cell surface receptor and antagonize in the presence of $\mathrm{T}_{4}$ ( Lin et al. 2008a). The identification of this new mechanism involving HMGA2, $\beta$-catenin and chibby family member 1 therefore suggests that the potentiation of the effect of resveratrol by tetrac may be much more important in situations of thyroid dysfunction with high $\mathrm{T}_{4}$ production.

Similar to resveratrol, tetrac is a multi-target anticancer agent. Indeed, tetrac modulates the expression of several genes in cancer cells, which govern cell survival, angiogenesis and metastasis (Davis et al. 2014). In the present study, we found that tetrac and resveratrol downregulated CTNNB1, HMGA2 and HIF1A genes expression (Fig. 8A). Both agents also downregulated the anti-apoptotic genes XIAP, MCL1, the proliferative genes $c-M y c, C C N D 1$ and PCNA, the angiogenic genes VEGFA and FGF2 and the metastatic genes MMP2, MMP9 and MMP13 (Fig. 8B, C, D and E), which is consistent with the findings of previous studies (Glinskii et al. 2009, Davis et al. 2014). Furthermore, the combination of resveratrol and tetrac showed a synergistic effect on most of the above-mentioned genes, suggesting that the mechanisms involved in the living organism are far more complex and outweigh the potentiation of nuclear COX-2 accumulation alone.

Since the seminal work of Jang and coworkers (Jang et al. 1997), a wealth of knowledge has been collected on the anti-cancer properties of resveratrol in vitro and in vivo. However, pharmacokinetics studies soon revealed a potential drawback for the translation of the stilbene into clinical use. Indeed, extensive intestinal and hepatic metabolisms undermine the systemic bioavailability of unchanged resveratrol, which is otherwise, satisfactorily absorbed (Walle et al. 2004). Therefore, it has been speculated that if resveratrol directly acts on the intestinal epithelium, the anti-cancer potential of the stilbene in distant organs might be attributable to its sulfate and glucuronide metabolites, which retain some biological activities (Hoshino et al. 2010). Elsewhere, resveratrol is well tolerated in healthy individuals, but some serious 


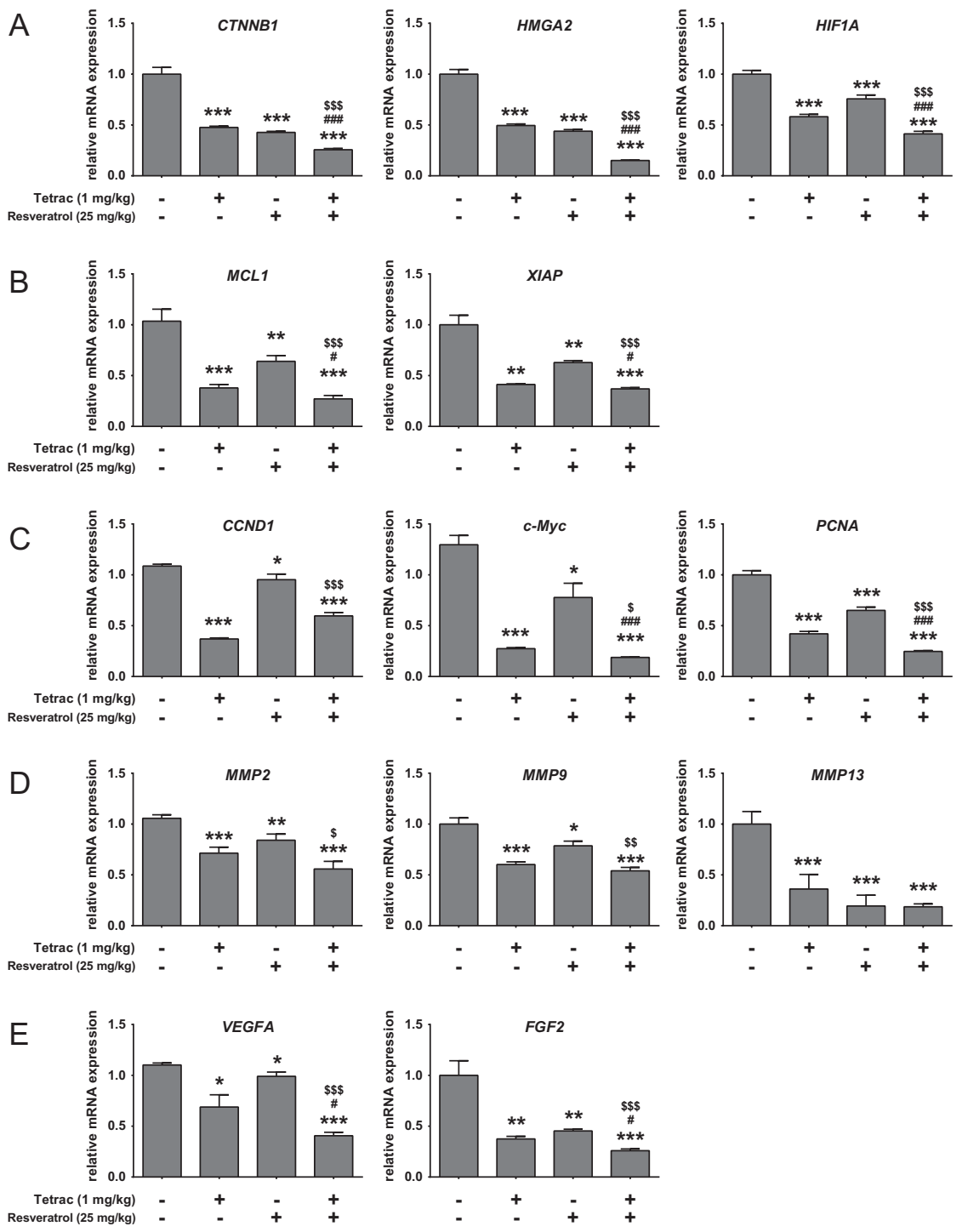

\section{Figure 8}

Tetrac and resveratrol regulate the expression of cancer genes in vivo. The level of expression of genes was detected by qPCR experiments. (A) CTNNB1, HMGA2, HIF1A. (B), Apoptosisrelated genes $M C L 1, X I A P$. (C) Proliferationrelated genes CCND1, c-Myc, PCNA. (D) Metastatic genes MMP2, MMP9, MMP13. (E) Angiogenesisrelated genes VEGFA and FGF2. Data are shown as the mean \pm s.D. of three experiments. ${ }^{*} P<0.05$, $* * P<0.01, * * * P<0.001$ compared with control, $\# P<0.05, \# \# P<0.001$ compared with tetrac $1 \mathrm{mg} / \mathrm{kg}$ alone, $\$ P<0.05, \$ \$ P<0.01$, $\$ \$ P<0.001$ compared with resveratrol $25 \mathrm{mg} / \mathrm{kg}$ alone. adverse effects have been noted in already-diseased people (Boocock et al. 2007, Patel et al. 2011, Popat et al. 2013, Tani et al. 2014). In animal studies, several concentrations have been described in the literature, as summarized elsewhere (Baur \& Sinclair 2006, Carter et al. 2014). In our study, we wanted to compare the potentiating effect of tetrac on resveratrol's anti-cancer abilities, at low dose $2.5 \mathrm{mg} / \mathrm{kg}$ (similar to Kimura \& Okuda 2001), and at a higher dose, $25 \mathrm{mg} / \mathrm{kg}$ (similar to Garvin et al. 2006). The intraperitoneal injection was done to prevent the massive biodegradation undergone by resveratrol in the small intestine when orally administered, but also to hold control of the concentrations effectively administered to animals. Tetrac, which is a naturally occurring derivative of $\mathrm{T}_{4}$, represents less than $1 \%$ of circulating thyroid hormones (Davis et al. 2013). In physiological conditions, tetrac exerts a thyro-mimetic effect and inhibits the release of thyroid-stimulating hormone (TSH) by the pituitary gland (Burger et al. 1979, Moreno et al. 2008). Clinical trials with tetrac at therapeutic doses are yet to be conducted to assess the full spectrum of its biological effect on human being. In animal models, tetrac and its nanoparticulate analog nano-diamino-tretrac did not induce adverse effects (Yalcin et al. 2009). In our study, tetrac $1 \mathrm{mg} / \mathrm{kg}$ was used in accordance with previous studies (Yalcin et al. 2009, Mousa et al. 2012, Yoshida et al. 2012). Both resveratrol and tetrac were well tolerated, and no adverse effect was observed (Fig. 5C).

In summary, this study aimed at deciphering whether tetrac, the de-aminated analog and antagonist of $\mathrm{T}_{4}$, potentiates the anti-cancer ability induced by resveratrol. We found that tetrac promoted resveratrol-induced antiproliferation in colon cancer cell lines, in colon cancer primary cells and enhanced the anti-tumoral effect of 
resveratrol in a mouse xenograft model of colon cancer. Western blot and immunohistochemistry analyses showed that tetrac enhanced resveratrol-induced nuclear COX-2 accumulation, which has been described as essential for resveratrol-induced apoptosis in cancer cells. Tetrac inhibited the nuclear accumulation of both HMGA2 and $\beta$-catenin, but enhanced chibby family member 1 , the nuclear $\beta$-catenin antagonist. Silencing either $\beta$-catenin or HMGA2 promoted resveratrol-induced COX-2 nuclear accumulation and anti-proliferation, suggesting that tetrac potentiated resveratrol's anticancer features via inhibition of HMGA2 and $\beta$-catenin nuclear accumulation. Additionally, tetrac and resveratrol individually and synergistically inhibited several genes relevant to cancer growth, angiogenesis and metastasis in vivo.

\section{Supplementary data}

This is linked to the online version of the paper at https://doi.org/10.1530/ ERC-17-0450.

\section{Declaration of interest}

Co-authors Paul J Davis and Shaker A Mousa are co-inventors of Nanotetrac, a nanoparticulate analog of tetrac. The other authors declare no conflict of interest to disclose.

\section{Funding}

This work was supported by grants from the Ministry of Science and Technology, Taiwan (MOST104-2320-B-038-009; MOST105-2320-B-038-006; MOST 104-2314-B-038 -046-MY3).

\section{Author contribution statement}

Concept and design of experiments: $\mathrm{A} \mathrm{W} \mathrm{N}$ and $\mathrm{H} \mathrm{Y} \mathrm{L}$. Acquisition of data: A W N, Y T C, C Y L, Y J S, and Y R C. Analysis and interpretation of data: A W N, Y T C, C Y L, J Z P, S I, and H Y L. Writing and review of the manuscript: A W N, Y T C and H Y L. Supervision of the work: H Y L, W S L, E F, S A M, C A C, L F L, J A B, Y H, JW P and P J D.

\section{Acknowledgments}

The authors would like to thank Jorie Larson MPH, for her contribution in proofreading this paper.

\section{References}

Almeida L, Vaz-da-Silva M, Falcao A, Soares E, Costa R, Loureiro AI, Fernandes-Lopes C, Rocha JF, Nunes T, Wright L, et al. 2009 Pharmacokinetic and safety profile of trans-resveratrol in a rising multiple-dose study in healthy volunteers. Molecular Nutrition and Food Research 53 (Supplement 1) S7-S15. (https://doi.org/10.1002/ mnfr.200800177)
Ayoubi TA, Jansen E, Meulemans SM \& Van de Ven WJ 1999 Regulation of HMGIC expression: an architectural transcription factor involved in growth control and development. Oncogene 18 5076-5087. (https://doi.org/10.1038/sj.onc.1202881)

Basu S, Haase G \& Ben-Ze'ev A 2016 Wnt signaling in cancer stem cells and colon cancer metastasis. F1000Research 5 699. (https://doi. org/10.12688/f1000research.7579.1)

Baur JA \& Sinclair DA 2006 Therapeutic potential of resveratrol: the in vivo evidence. Nature Reviews Drug Discovery 5 493. (https://doi. org/10.1038/nrd2060)

Boocock DJ, Faust GES, Patel KR, Schinas AM, Brown VA, Ducharme MP, Booth TD, Crowell JA, Perloff M, Gescher AJ, et al. 2007 Phase I dose escalation pharmacokinetic study in healthy volunteers of resveratrol, a potential cancer chemopreventive agent. Cancer Epidemiology Biomarkers and Prevention 16 1246-1252. (https://doi. org/10.1158/1055-9965.EPI-07-0022)

Burger AG, Engler D, Sakoloff C \& Staeheli V 1979 The effects of tetraiodothyroacetic and triiodothyroacetic acids on thyroid function in euthyroid and hyperthyroid subjects. Acta Endocrinologica 92 455-467. (https://doi.org/10.1530/acta.0.0920455)

Carter LG, D'Orazio JA \& Pearson KJ 2014 Resveratrol and cancer: focus on in vivo evidence. Endocrine-Related Cancer 21 R209-R225. (https://doi.org/10.1530/ERC-13-0171)

Chin YT, Yang SH, Chang TC, Changou CA, Lai HY, Fu E, HuangFu WC, Davis PJ, Lin HY \& Liu LF 2015 Mechanisms of dihydrotestosterone action on resveratrol-induced anti-proliferation in breast cancer cells with different ERalpha status. Oncotarget 6 35866-35879. (https://doi.org/10.18632/oncotarget.5482)

Clevers H \& Nusse R 2012 Wnt/beta-catenin signaling and disease. Cell 149 1192-1205. (https://doi.org/10.1016/j.cell.2012.05.012)

Cohen K, Abadi U, Hercbergs A, Davis PJ, Ellis M \& Ashur-Fabian O 2018 The induction of myeloma cell death and DNA damage by tetrac, a thyroid hormone derivative. Endocrine-Related Cancer 25 21-34. (https://doi.org/10.1530/ERC-17-0246)

Cottart CH, Nivet-Antoine V, Laguillier-Morizot C \& Beaudeux JL 2010 Resveratrol bioavailability and toxicity in humans. Molecular Nutrition and Food Research 54 7-16. (https://doi.org/10.1002/ mnfr.200900437)

Davis PJ, Davis FB, Luidens MK, Lin H-Y \& Mousa SA 2013 Tetraiodothyroacetic acid (Tetrac), nanotetrac and anti-angiogenesis In Angiogenesis Modulations in Health and Disease: Practical Applications of Pro- and Anti-angiogenesis Targets, pp 107-117. Eds SA Mousa \& PJ Davis. Dordrecht, Netherlands: Springer. (https://doi.org/10.1007/978-94-007-6467-5_10)

Davis PJ, Glinsky GV, Lin H-Y, Leith JT, Hercbergs A, Tang H-Y, AshurFabian O, Incerpi S \& Mousa SA 2014 Cancer cell gene expression modulated from plasma membrane integrin $\alpha v \beta 3$ by thyroid hormone and nanoparticulate tetrac. Frontiers in Endocrinology 5240. (https://doi.org/10.3389/fendo.2014.00240)

Fusco A \& Fedele M 2007 Roles of HMGA proteins in cancer. Nature Reviews Cancer 7 899-910. (https://doi.org/10.1038/nrc2271)

Garvin S, Ollinger K \& Dabrosin C 2006 Resveratrol induces apoptosis and inhibits angiogenesis in human breast cancer xenografts in vivo. Cancer Letters 231 113-122. (https://doi.org/10.1016/j. canlet.2005.01.031)

Gharagozloo M, Mirzaei HR, Bagherpour B, Rezaei A, Kalantari H, Sanei MH, Hosseini M, Mohajeri G, Tabatabai A \& Hashemi M 2012 Cell cycle analysis of the CD133(+) and CD133(-) cells isolated from human colorectal cancer. Journal of Cancer Research and Therapeutics 8 399-403. (https://doi.org/10.4103/09731482.103520)

Glinskii AB, Glinsky GV, Lin HY, Tang HY, Sun M, Davis FB, Luidens MK, Mousa SA, Hercbergs AH \& Davis PJ 2009 Modification of survival pathway gene expression in human breast cancer cells by tetraiodothyroacetic acid (tetrac). Cell Cycle 8 3562-3570. (https://doi.org/10.4161/cc.8.21.9963) 
Günther K, Foraita R, Friemel J, Günther F, Bullerdiek J, Nimzyk R, Markowski DN, Behrens T \& Ahrens W 2017 The stem cell factor HMGA2 is expressed in non-HPV-associated head and neck squamous cell carcinoma and predicts patient survival of distinct subsites. Cancer Epidemiology, Biomarkers and Prevention 26 197-205. (https;//doi.org/10.1158/1055-9965)

Hercbergs AH, Ashur-Fabian O \& Garfield D 2010 Thyroid hormones and cancer: clinical studies of hypothyroidism in oncology. Current Opinion in Endocrinology, Diabetes and Obesity 17 432-436. (https://doi.org/10.1097/MED.0b013e32833d9710)

Hoshino J, Park E-J, Kondratyuk TP, Marler L, Pezzuto JM, van Breemen RB, Mo S, Li Y \& Cushman M 2010 Selective synthesis and biological evaluation of sulfate-conjugated resveratrol metabolites. Journal of Medicinal Chemistry 53 5033-5043. (https://doi. org $/ 10.1021 / j m 100274 \mathrm{c}$ )

Jang M, Cai L, Udeani GO, Slowing KV, Thomas CF, Beecher CWW, Fong HHS, Farnsworth NR, Kinghorn AD, Mehta RG, et al. 1997 Cancer chemopreventive activity of resveratrol, a natural product derived from grapes. Science 275 218-220. (https://doi.org/10.1126/ science.275.5297.218)

Khan SR, Chaker L, Ruiter R, Aerts JG, Hofman A, Dehghan A, Franco OH, Stricker BH \& Peeters RP 2016 Thyroid function and cancer risk: the Rotterdam study. Journal of Clinical Endocrinology and Metabolism 101 5030-5036. (https://doi.org/10.1210/jc.20162104)

Kimura Y \& Okuda H 2001 Resveratrol isolated from polygonum cuspidatum root prevents tumor growth and metastasis to lung and tumor-induced neovascularization in lewis lung carcinoma-bearing mice. Journal of Nutrition 131 1844-1849.

Lee Y-S, Chin Y-T, Yang Y-CSH, Wei P-L, Wu H-C, Shih A, Lu Y-T, Pedersen JZ, Incerpi S, Liu LF, et al. 2016 The combination of tetraiodothyroacetic acid and cetuximab inhibits cell proliferation in colorectal cancers with different K-ras status. Steroids 111 63-70. (https://doi.org/10.1016/j.steroids.2016.03.006)

Leith JT, Davis PJ, Mousa SA \& Hercbergs AA 2017 In vitro effects of tetraiodothyroacetic acid combined with $\mathrm{X}$-irradiation on basal cell carcinoma cells. Cell Cycle 16 367-373. (https://doi.org/10.1080/1538 4101.2016.1269044)

Li Y, Zhao Z, Xu C, Zhou Z, Zhu Z \& You T 2014 HMGA2 induces transcription factor Slug expression to promote epithelial-tomesenchymal transition and contributes to colon cancer progression. Cancer Letters 355 130-140. (https://doi.org/10.1016/j. canlet.2014.09.007)

Liao C-H, Yeh S-C, Huang Y-H, Chen R-N, Tsai M-M, Chen W-J, Chi HC, Tai P-J, Liao C-J, Wu S-M, et al. 2010 Positive regulation of spondin 2 by thyroid hormone is associated with cell migration and invasion. Endocrine-Related Cancer 17 99-111. (https://doi. org/10.1677/ERC-09-0050)

Lin H-Y 2016 Abstract C96: thyroid hormone induced Beta-catenindependent proliferation in colorectal cancer cells. Molecular Cancer Therapeutics 14 C96. (https://doi.org/10.1158/1535-7163.TARG15-C96)

Lin H-Y, Tang H-Y, Shih A, Keating T, Cao G, Davis PJ \& Davis FB 2007 Thyroid hormone is a MAPK-dependent growth factor for thyroid cancer cells and is anti-apoptotic. Steroids 72 180-187. (https://doi. org/10.1016/j.steroids.2006.11.014)

Lin H-Y, Tang H-Y, Keating T, Wu Y-H, Shih A, Hammond D, Sun M, Hercbergs A, Davis FB \& Davis PJ 2008a Resveratrol is pro-apoptotic and thyroid hormone is anti-apoptotic in glioma cells: both actions are integrin and ERK mediated. Carcinogenesis 29 62-69. (https://doi. org/10.1093/carcin/bgm239)

Lin HY, Sun M, Tang HY, Simone TM, Wu YH, Grandis JR, Cao HJ, Davis PJ \& Davis FB 2008b Resveratrol causes COX-2- and p53dependent apoptosis in head and neck squamous cell cancer cells. Journal of Cellular Biochemistry 104 2131-2142. (https://doi. $\operatorname{org} / 10.1002 / j \mathrm{jcb} .21772)$
Lin HY, Landersdorfer CB, London D, Meng R, Lim CU, Lin C, Lin S, Tang HY, Brown D, Van Scoy B, et al. 2011a Pharmacodynamic modeling of anti-cancer activity of tetraiodothyroacetic acid in a perfused cell culture system. PLOS Computational Biology 7 e1001073. (https://doi.org/10.1371/journal.pcbi.1001073)

Lin HY, Tang HY, Davis FB \& Davis PJ 2011b Resveratrol and apoptosis. Annals of the New York Academy of Sciences 1215 79-88. (https://doi. org/10.1111/j.1749-6632.2010.05846.x)

Lin H-Y, Chin Y-T, Nana AW, Shih Y-J, Lai H-Y, Tang H-Y, Leinung M, Mousa SA \& Davis PJ 2016a Actions of 1-thyroxine and Nanodiamino-tetrac (Nanotetrac) on PD-L1 in cancer cells. Steroids $\mathbf{1 1 4}$ 59-67. (https://doi.org/10.1016/j.steroids.2016.05.006)

Lin HY, Chin YT, Yang YC, Lai HY, Wang-Peng J, Liu LF, Tang HY \& Davis PJ $2016 b$ Thyroid hormone, cancer, and apoptosis. Comprehensive Physiology 6 1221-1237. (https://doi.org/10.1002/cphy. c150035)

Moeller LC \& Führer D 2013 Thyroid hormone, thyroid hormone receptors, and cancer: a clinical perspective. Endocrine-Related Cancer 20 R19-R29. (https://doi.org/10.1530/ERC-12-0219)

Moreno M, de Lange P, Lombardi A, Silvestri E, Lanni A \& Goglia F 2008 Metabolic effects of thyroid hormone derivatives. Thyroid $\mathbf{1 8}$ 239-253. (https://doi.org/10.1089/thy.2007.0248)

Morin PJ, Sparks AB, Korinek V, Barker N, Clevers H, Vogelstein B \& Kinzler KW 1997 Activation of $\beta$-catenin-Tcf signaling in colon cancer by mutations in $\beta$-catenin or APC. Science 275 1787-1790. (https://doi.org/10.1126/science.275.5307.1787)

Morishita A, Zaidi MR, Mitoro A, Sankarasharma D, Szabolcs M, Okada Y, D'Armiento J \& Chada K 2013 HMGA2 is a driver of tumor metastasis. Cancer research 73 4289-4299. (https://doi. org/10.1158/0008-5472.CAN-12-3848)

Mousa SA, Yalcin M, Bharali DJ, Meng R, Tang H-Y, Lin H-Y, Davis FB \& Davis PJ 2012 Tetraiodothyroacetic acid and its nanoformulation inhibit thyroid hormone stimulation of non-small cell lung cancer cells in vitro and its growth in xenografts. Lung Cancer 76 39-45. (https://doi.org/10.1016/j.lungcan.2011.10.003)

Patel KR, Scott E, Brown VA, Gescher AJ, Steward WP \& Brown K 2011 Clinical trials of resveratrol. Annals of the New York Academy of Sciences 1215 161-169. (https://doi.org/10.1111/j.1749-6632.2010.05853.x)

Popat R, Plesner T, Davies F, Cook G, Cook M, Elliott P, Jacobson E, Gumbleton T, Oakervee H \& Cavenagh J 2013 A phase 2 study of SRT501 (resveratrol) with bortezomib for patients with relapsed and or refractory multiple myeloma. British Journal of Haematology $\mathbf{1 6 0}$ 714-717. (https://doi.org/10.1111/bjh.12154)

Rebbaa A, Chu F, Davis FB, Davis PJ \& Mousa SA 2008 Novel function of the thyroid hormone analog tetraiodothyroacetic acid: a cancer chemosensitizing and anti-cancer agent. Angiogenesis 11 269-276. (https://doi.org/10.1007/s10456-008-9110-8)

Schmohl KA, Müller AM, Wechselberger A, Rühland S, Salb N, Schwenk N, Heuer H, Carlsen J, Göke B, Nelson PJ, et al. 2015 Thyroid hormones and tetrac: new regulators of tumour stroma formation via integrin $\alpha \mathrm{v} \beta 3$. Endocrine-Related Cancer 22 941-952. (https://doi.org/10.1530/ERC-15-0245)

Shi X, Tian B, Ma C, Liu L, Zhang N, Na Y, Li J, Lu J \& Qiao Y 2017 GSK3beta activity is essential for senescence-associated heterochromatin foci (SAHF) formation induced by HMGA2 in WI38 cells. American Journal of Translational Research 9 167-174.

Takemaru K-I, Yamaguchi S, Lee YS, Zhang Y, Carthew RW \& Moon RT 2003 Chibby, a nuclear [beta]-catenin-associated antagonist of the Wnt/Wingless pathway. Nature 422 905-909. (https://doi. org/10.1038/nature01570)

Tani H, Hikami S, Iizuna S, Yoshimatsu M, Asama T, Ota H, Kimura Y, Tatefuji T, Hashimoto K \& Higaki K 2014 Pharmacokinetics and safety of resveratrol derivatives in humans after oral administration of melinjo (Gnetum gnemon L.) seed extract powder. Journal of Agricultural and Food Chemistry 62 1999-2007. (https://doi. org/10.1021/jf4048435) 
Torre LA, Bray F, Siegel RL, Ferlay J, Lortet-Tieulent J \& Jemal A 2015 Global cancer statistics, 2012. CA: A Cancer Journal for Clinicians 65 87-108. (https://doi.org/10.3322/caac.21262)

Tseng SH, Lin SM, Chen JC, Su YH, Huang HY, Chen CK, Lin PY \& Chen Y 2004 Resveratrol suppresses the angiogenesis and tumor growth of gliomas in rats. Clinical Cancer Research 10 2190-2202. (https://doi.org/10.1158/1078-0432.CCR-03-0105)

Varoni EM, Lo Faro AF, Sharifi-Rad J \& Iriti M 2016 Anticancer molecular mechanisms of resveratrol. Frontiers in Nutrition 38. (https://doi.org/10.3389/fnut.2016.00008)

Walle T, Hsieh F, DeLegge MH, Oatis JE \& Walle UK 2004 High absorption but very low bioavailability of oral resveratrol in humans. Drug Metabolism and Disposition 32 1377-1382. (https://doi. org/10.1124/dmd.104.000885)

Wang X, Liu X, Li AY-J, Chen L, Lai L, Lin HH, Hu S, Yao L, Peng J \& Loera S 2011 Overexpression of HMGA2 promotes metastasis and impacts survival of colorectal cancers. Clinical Cancer Research 17 2570-2580. (https://doi.org/10.1158/1078-0432.CCR-10-2542)

Wend P, Runke S, Wend K, Anchondo B, Yesayan M, Jardon M, Hardie N, Loddenkemper C, Ulasov I \& Lesniak MS 2013 WNT10B/ $\beta$-catenin signalling induces HMGA2 and proliferation in metastatic triple-negative breast cancer. EMBO Molecular Medicine 5 264-279. (https://doi.org/10.1002/emmm.201201320)
Xi Y, Shen W, Ma L, Zhao M, Zheng J, Bu S, Hino S \& Nakao M 2016 HMGA2 promotes adipogenesis by activating C/EBP $\beta$-mediated expression of PPAR $\gamma$. Biochemical and Biophysical Research Communications 472 617-623. (https://doi.org/10.1016/j.bbrc.2016.03.015)

Yalcin M, Baharali DJ, Lansing L, Dyskin E, Mousa SS, Hercbergs A, Davis FB \& Davis PJ 2009 Tetraidothyroacetic acid (Tetrac) and tetrac nanoparticles inhibit growth of human renal cell carcinoma xenografts. Anticancer Research 29 3825-3831.

Yoshida T, Gong J, Xu Z, Wei Y \& Duh EJ 2012 Inhibition of pathological retinal angiogenesis by the integrin $\alpha \mathrm{v} \beta 3$ antagonist tetraiodothyroacetic acid (tetrac). Experimental Eye Research 94 41-48. (https://doi.org/10.1016/j.exer.2011.11.003)

Zentner MD, Lin HH, Deng HT, Kim KJ, Shih HM \& Ann DK 2001 Requirement for high mobility group protein HMGI-C interaction with STAT3 inhibitor PIAS3 in repression of alpha-subunit of epithelial $\mathrm{Na}+$ channel (alpha-ENaC) transcription by Ras activation in salivary epithelial cells. Journal of Biological Chemistry 276 29805-29814. (https://doi.org/10.1074/jbc. M103153200)

Zha L, Zhang J, Tang W, Zhang N, He M, Guo Y \& Wang Z 2013 HMGA2 elicits EMT by activating the Wnt/beta-catenin pathway in gastric cancer. Digestive Diseases and Sciences 58 724-733. (https://doi.org/10.1007/s10620-012-2399-6)

Received in final form 11 December 2017

Accepted 18 December 2017

Accepted Preprint published online 18 December 2017
(C) 2018 Society for Endocrinology Published by Bioscientifica Ltd. Printed in Great Britain 